Paul Bidwell (ed.), Proceedings of the XXIst International Limes (Roman Frontiers)

Congress 2009 at Newcastle upon Tyne (BAR International Series), Oxford 201?

\title{
The Empress and her Relationship to the Roman Army
}

\author{
Kai M. Töpfer (Heidelberg)
}

The empresses have hardly featured in studies on the relationship between the emperor and his army or on the system of patronage in military context. This seems astonishing considering the evident visual presence of the princesses and empresses in military settings since early imperial times. Against this background the following study investigates the role and the meaning of the Roman empresses in the world of the Roman army. Depictions of the Empresses in a military setting may serve as a starting point.

A very insightful example is the scabbard of a gladius in Bonn (fig. 1. Cf. Alföldi 1951, 77; Dahmen 2001, 105-106. 207 Nr. Mil 14; Künzl 1996, 401-402 Nr. M 3), which is decorated with a relief showing a female bust in frontal view flanked by two busts of boys. The female portrait has been identified either as Julia, the daughter of Augustus, with her sons C. and L. Caesar, or as Tiberius and Drusus the Elder with their mother Livia. Either way, for this study the precise identification is not crucial. Much more important is the composition of the portraits, which clearly visualises a primarily dynastic statement. This seems to be that the portrayed female is predominantly depicted in her role as mother of potential heirs to the throne (Dahmen 2001, 106. 207; Mlasowsky 1996, 376-377).

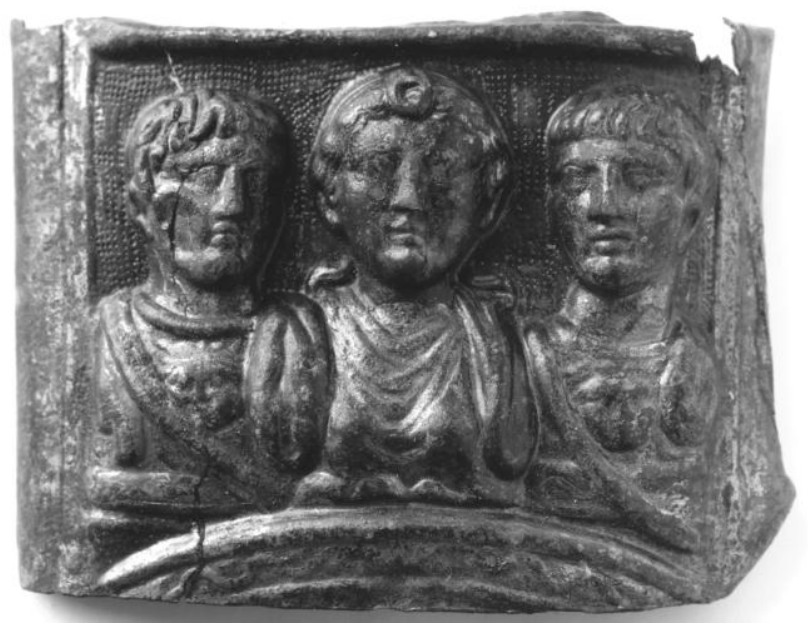

Fig. 1: Scabbard-Relief in Bonn, Landesmus., Inv. 4320.

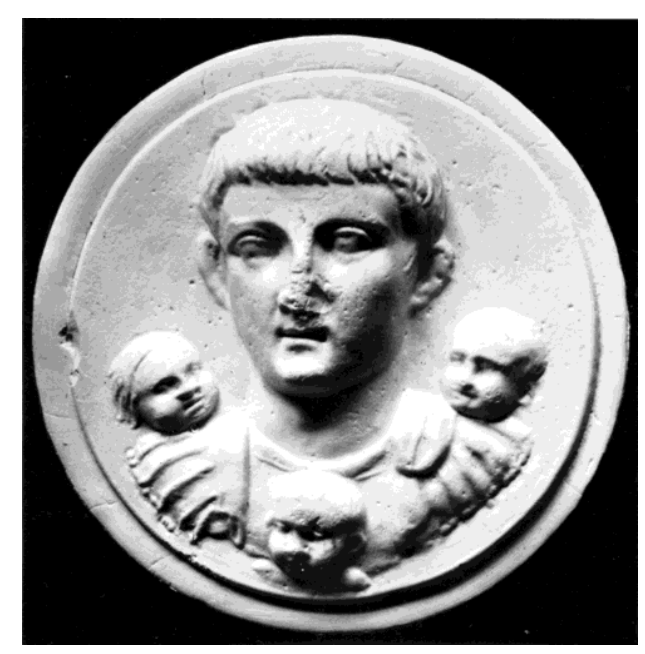

Fig. 2: Glass-phalera in Wien, Inv. XI B 8.

This propagation of a dynastic succession is similarly achieved by means of the glass phalerae (Alföldi 1951, 66-80; Boschung 1987, 223-258; Dahmen 2001, 115-117. 214221) that were given to soldiers and centurions as military decorations. This particular group of phalerae, distributed mainly during the Julio-Claudian period, was made in coloured, often blue glass and formed with moulds. The depictions on these glass phalerae always show heads or busts of members of the Julio-Claudian family, either individually or combined. One type, for instance, shows Tiberius with Germanicus and Drusus the Younger (Alföldi 1951, 70-72 Typ IV; Boschung 1987, 234-243; Dahmen 2001, 216-218 
Nr. Mil 32). On another type Claudius appears with his three children, thus with his son Britannicus and his daughters Octavia and Antonia (fig. 2. Cf. Alföldi 1951, 70 Typ III; Boschung 1987, 248-254; Dahmen 2001, 219-220 Nr. Mil 36). Seven examples of this type are preserved. They were taken from three moulds indicative of a wide circulation. Particularly striking is the depiction of Octavia and Antonia as young daughters of the emperor. In contrast to the supportive mother or wife of the emperor, the children are displayed to stress their possible future role for guaranteeing a succession to the throne. Furthermore in the depiction the princesses are not diminished in comparison with Britannicus as the male heir.

Another type of glass phalerae shows Agrippina the Elder (Alföldi 1951, 72 Typ VII; Boschung 1987, 247-248; Dahmen 2001, 219 Nr. Mil 35). Although she is not depicted with her husband or children, it is likely that other family members, such as Caligula or Claudius, were shown on further phalerae worn on the same harness as a set. Therefore, the portrait of Agrippina is probably equally intended to convey a dynastic message. Moreover, the fact that Agrippina is shown on one phalera on her own shows her significant role in the dynastic representation.

However, imperial women were not only present on weapons and medals. Images of female members of the imperial family were even attached to military standards highly significant symbols for the identity of units. This can be seen on reliefs from four EarlyImperial tombs of primipilii (Töpfer 2009), thus of the highest centurions of a legion. On each tomb, the decoration includes a number of standards that function primarily as a kind of code for the rank of the primuspilus since it was he who was in charge of keeping these signs (Dobson 1978, 65; Schäfer 1989, 293294). In addition Juvenal $(14,197)$ and Pliny (Nat. hist. 14,9) mention the eagle as a symbol for the primuspilus.

From two of the four tombs only fragmentary reliefs have survived. One is incorporated in a house in Venafro, Corso Lucenteforte 7 (fig. 3. Cf. Diebner 1979, 238-240 Nr. VF 32; Keppie 1984, 229-230 Nr. 14b). It shows a legionary eagle flanked by two standards. The one on the left is better

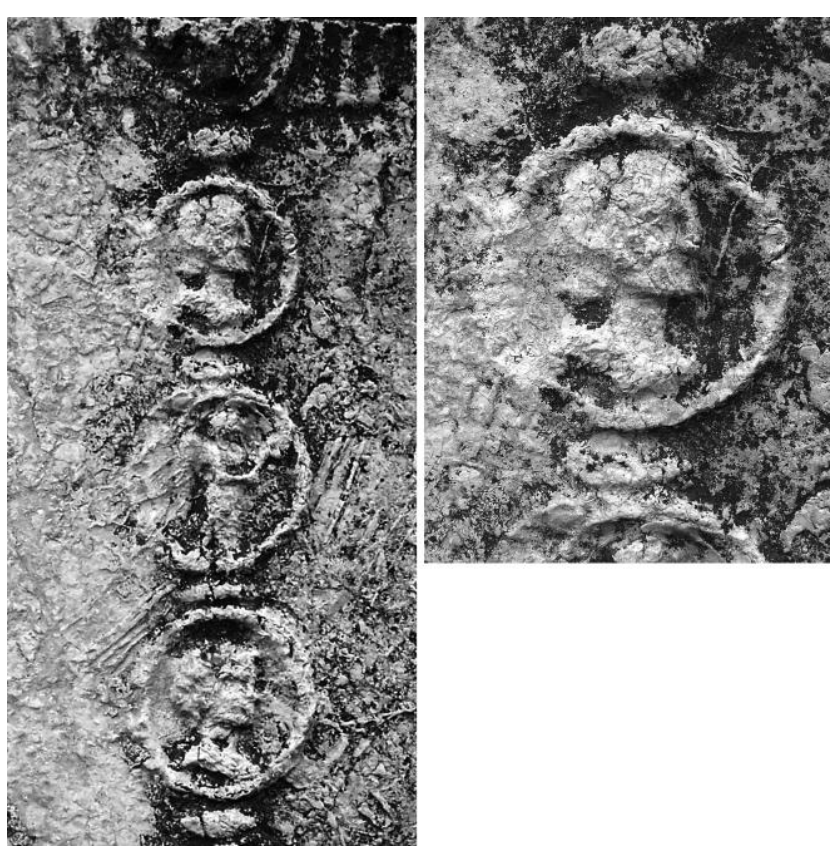

Fig. 3: Fig. 3. Relief from a monumental tomb, immured at Venafro. preserved and is equipped with some decorated phalerae. They show, from the bottom up, a bound barbarian on top of a pile of weapons, a male bust in profile to the right, the goddess Victoria, and a female bust to the right. Here, the bun at the neck leaves no doubt about her gender. The hairstyle seems best suited to Livia, assuming that only members of the imperial family were depicted on standards. 
Two reliefs, which clearly belonged to another tomb, are immured in the Cathedral of Venfaro (Boschung 1987, 225-226; Diebner 1979, 237-238 Nr. Vf 31). They show two standards with small-scale portraits. Whilst one portrait is likely to depict a male person, the other has slimmer outlines and the hair bound to a nodus, a style that was only worn by women. It is reasonable to assume that this is again Livia, since she is known to have been depicted with this hairstyle in early portraits.

Some more reliefs are preserved from the tomb of the Titecii in Trasacco (Strazzulla 2001, 172-178; Liberatore and Strazzulla 2007, 57-116), in which at least two primipili and some more family members were buried. The decoration shows a lot of military objects including two legionary eagles and four other standards. A small portrait bust in a shelllike frame is attached on the top of two of them. Whilst the more damaged head has a hairstyle of a man, the other portrait has already been convincingly identified by Maria Strazzulla as female. This female head can best be identified with portrait types of Agrippina the Younger.

The last example is the tomb of the primuspilus Marcus Paccius Marcellus in S. Guglielmo al Goleto (Coarelli 1967; Lipps and Töpfer 2009; Schäfer 1989, 292-304). Here three standards are depicted, two of which are equipped with portrait phalerae. Whilst one of the discs shows a male, the other one seems to show a female head. This is apparent from the depiction of breasts, as well as by the hairstyle. Instead of being the hairstyle of Titus or Domitian, as had been suggested (Schäfer 1989, 298), it seems to be that of Livia, probably in the so-called Ceres-type.

So the question which now arises is, how should we assess this visual presence of female members of the imperial family in the Early Imperial army?

On the relief of the scabbard and the glass phalerae the female portraits are always part of a dynastic iconographic programme. Equally the combination of female with male portraits on standards is likely to have a similar dynastic message. The three women mostly depicted are Livia and the two Agrippinae. They all played a significant role in the succession to the throne (Cf. Rose 1997, 23-24. 33-35; Wood 1999, 75-141. 203-248): Livia as the wife of the first princeps Augustus and as mother of Tiberius, who was not related to him by blood; Agrippina the Elder as the granddaughter of Augustus and the mother of Caligula; Agrippina the Younger as the wife of Claudius and mother of Nero who was only distantly related to Claudius. In fact, Tiberius, Caligula and Nero were adopted so that there was a legal father-son relationship. However, a relationship by blood via the biological mother seems to have been of further significance for the legitimisation of the emperor. This also becomes apparent with the depiction of the two princesses Octavia and Antonia with Claudius on the glass phalera mentioned above, where they are put on view for showing their power to guarantee the legitimisation of future emperors. It is noteworthy that in the depiction the princesses are not degraded in comparison with Britannicus, the male heir.

A very interesting statement about the relationship between the Roman army and the women of the imperial family is to be found by Tacitus (Tac. Ann. I 69). Writing about the year $15 \mathrm{AD}$, when the army of Germanicus returned to the river Rhine after a very hard campaign, he tells us that Agrippina the Elder, after she had prevented the destruction of 
the bridge, welcomed the Roman army at the bridgehead, and bestowed praise and thanks on the returning legions. Furthermore she helped some soldiers, who needed clothes or medicine. According to Tacitus, Tiberius was very indignant over this. The reason for his indignation is clearly because Agrippina was trying to establish something like a patronclient system between herself and the Rhine army, in order to support her husband Germancius and her son Caligula. So Tacitus imagines Tiberius' thoughts: "Agrippina had now more power with the armies than officers, than generals".

However, the significance of imperial women as a dynastic link is not restricted to the imagery of the military world. On the contrary, there are portrait galleries and reliefs spread all over the Roman Empire that show the imperial women mentioned before as well as further female members of the imperial family as part of a dynastic propaganda (Rose 1997, 57-77). Examples are the impressive reliefs of the Sebasteion in Aphrodisias in modern Turkey (Cf. Smith 2013). On the upper floors of two long porticos a number of reliefs were put up that glorified the imperial family and its individual members (Rose 1997, 164-169; Smith 2013). Two of the reliefs show Agrippina minor, once as the wife of Claudius, united with him by clasped hands, and once as the mother of Nero (fig. 4). In order to underline her role as the benedictory mother of the emperor, she is shown as Tyche who crowns her son and thus promises a positive future for the realm under his rule. Thus, the staging of the empresses in a military context does not differ from that in a civil context. There was no role for the empresses specifically adjusted to the needs of soldiers. In other words, the soldiers regarded the women of the imperial family the same way as did the rest of the population. Only the medium for the depiction was chosen according to their needs. Instead of immobile reliefs and galleries of statues, there were decorated weapons, medals and portraits for the standards which accompanied the soldiers everywhere.

The objects discussed demonstrate that the women of the Julio-Claudian family played an important role in the clientpatron relation between the army and the Emperor (Cf. Alföldi 1951, 77). They and their children also enjoyed the soldiers' loyalty. Therefore they could, even if they never ruled the Empire, establish and support a legal succession to the throne.

With the end of the Julio-Claudian

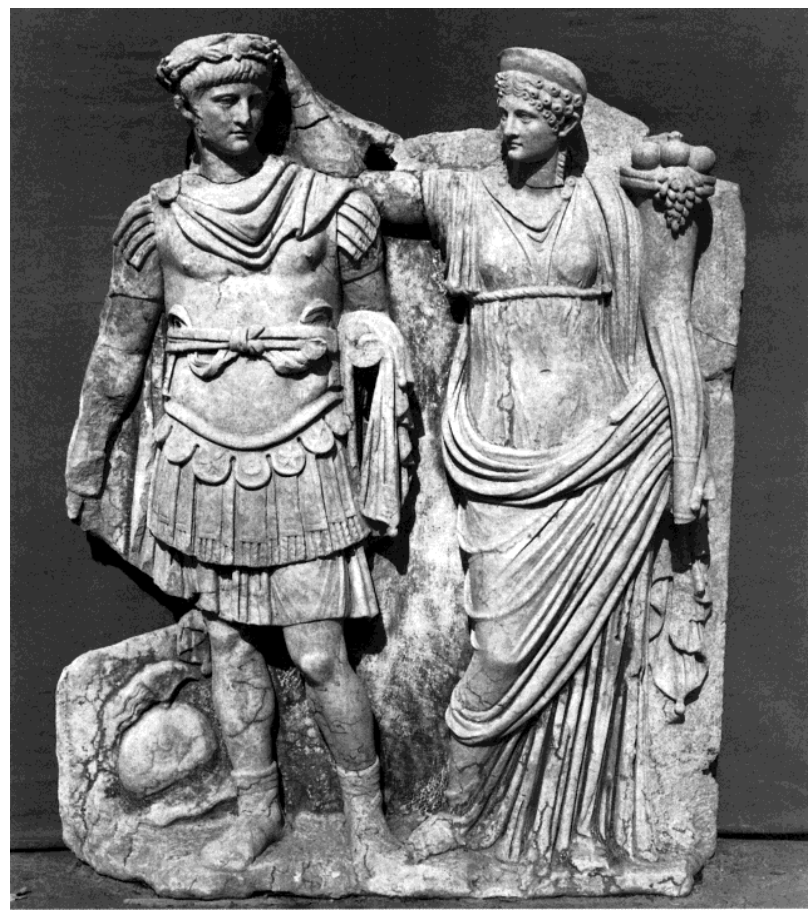

Fig. 4: Relief from Aphrodisias. After Alexandridis 2004, pl. $27,2$.

dynasty the decoration of military equipment and thus of the imagery of the soldiers' environment changes markedly: the production of glass phalerae ceases and portraits disappear from the decorations of the most military objects (Künzl 1996; Künzl 2009, 89). This seems to have affected even the standards. Solely on standards of praetorians do we 
find medals with portraits, but then only male busts (Töpfer 2011). Moreover, from now on, imperial women clearly play a minor role in the dynastic representation (Alexandridis 2004, 107-108). These two developments are mutually reinforcing. Firstly, military imagery employs fewer depictions of portraits, and secondly, the public imagery of imperial women generally changed (Alexandridis 2004, 101).

Among the Flavians only the nearest female members of the imperial family were displayed in official portrait galleries, but not to underline a dynastic legitimisation. In fact, this might be due to the early death of Flavia Domitilla and the concubinage with Antonia Caenis, neither of whom could be used for a stabilisation of the dynasty. Obviously the empresses had no significance for the legitimisation of the Five Good Emperors, since adoption was the sole link to the predecessor. Indeed, though portraits of the empresses are well known, for instance on coinage, these images play hardly any role in a dynastic sense, and in the visual environment of the military, these women seem not to have been present at all.

This situation fundamentally changes under Marcus Aurelius. After almost one century it was he who tried to re-establish the biological succession to the throne. For that he depended in particular on the loyalty of the soldiers. Different coin images document his efforts to evoke a close relationship between his son Commodus and the soldiers. For instance, on a reverse showing clasped hands in front of a military standard Commodus is declared as princeps iuventutis (RIC 1548-1549) or his portrait on the obverse is combined with the Fides Militum on the reverse (RIC 638-639). In addition, Marcus Aurelius created for his wife Faustina the Younger, Commodus' mother, the hitherto unknown title Mater castrorum (fig. 5. Cf. Alexandridis 2004, 16; Boatwright 2003), so that she, too, could assume a military role. The intention was not so much to bring the empress personally closer to the soldiers, than to establish a loyal relationship between the army and Commodus via their loyalty to his mother. Thus, the empress, as daughter, wife and mother, now stands for a dynasty that holds the imperium and needs to reclaim the loyalty of the army. Aymard fittingly described this function of Faustina, who legally had neither military authority nor imperium, as "régence morale" (Aymard 1950, 75).
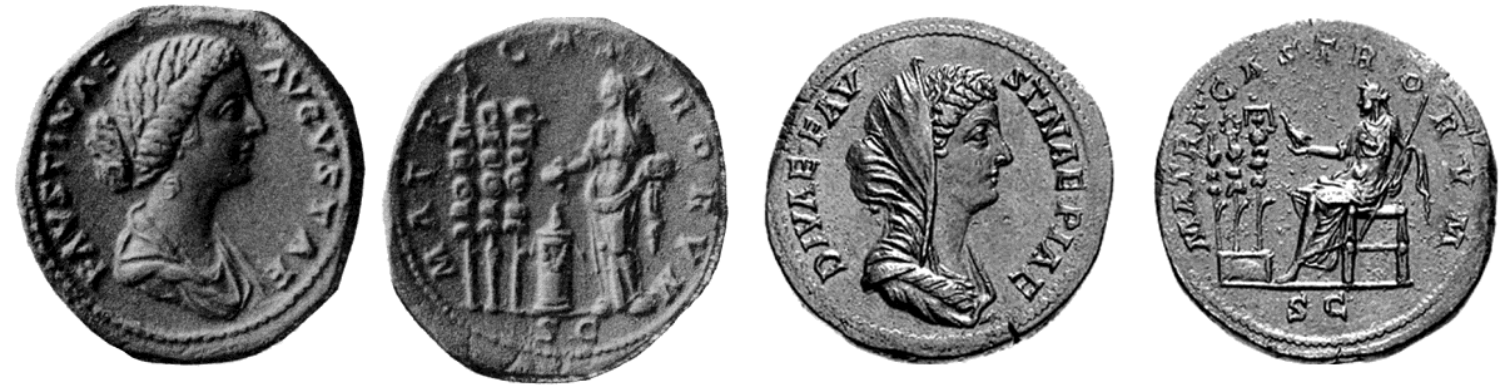

Fig. 5: Sestertii for Faustina minor, RIC 1711 and 1660.

The soldiers accepted Faustina as an important part of the dynasty and of the patron-clientsystem, for enabled her to function as an additional factor in legitimising and supporting Commodus as heir to the throne. The acceptance of the title Mater castrorum by the soldiers is confirmed by its renewal under the Severans; then not only Iulia Domna, the wife of Septimius Severus is honoured with this title, but also Iulia Mamaea, the niece of Iulia Domna and mother of Severus Alexander, who was not related with Septimius 
Severus by blood. If the title Mater castrorum had not achieved the intended result under Marcus Aurelius, it would hardly have been renewed under the Severans. Furthermore among the Severans we find the first monumental statues of imperial women in Roman forts (Stoll 1992, 201-202).

In conclusion, the examples discussed reveal that particularly within the context of biological succession to the throne, the visual presence of empresses played an important role in the imagery of the Roman army. The female members of the imperial family are here put on view according to the same role perception that was shown in civil context: thus as the wife, mother or daughter of the current emperor (Cf. Corbier 1995, 173-193. Wood 1999, 315-319). This is in particular noteworthy since it means that soldiers were not merely focussed on the male members of the imperial family and nor solely on the military leader of the imperium himself (Alföldi 1951, 77). Biological relationship, even if it was established by the female line, was a possible legitimisation for a future emperor in the eyes of both the civil population and the soldiers. This phenomenon shows, once again, that the Roman army was no isolated environment, separated from the civilian world. The conception of the gender roles was basically similar.

\section{Abbreviations:}

Alexandridis, A. 2004. Die Frauen des römischen Kaiserhauses. Mainz, Zabern.

Alföldi, A. 1951. Römische Porträtmedaillons aus Glas, Ur-Schweiz 15, 66-80.

Aymard, J. 1950. L'“adventus“" de Marc-Aurèle sur l'arc de Constantin, Revue Ètudes Anciennes 52, 71-76.

Boatwright, M.T. 2003. Faustina the Younger, Mater castrorum., in Frei-Stolba, R. et al. (eds.), Les femmes antiques entre sphère privée et sphère publique. Actes du diplôme d'études avancées, Universités de Lausanne et Neuchâtel, 2000-2002, 249-268. Bern/Frankfurt am Main, Lang.

Boschung, D. 1987. Römische Glasphalerae mit Porträtbüsten, Bonner Jahrbücher 187, 223-258.

Coarelli, F. 1967. Su un monumento funerario Romano nell'abbazia di San Guglielmo al Goleto. Dialoghi di archeologia 1, 46-71.

Corbier, M. 1995. Male Power and legitimacy through women: the domus Augusta under the Iulio-Claudians, in R. Hawley - B. Levick (eds.), Women in Antiquity. New Assessments, 173-193. London/New York, Routledge.

Dahmen, K. 2001. Untersuchungen zu Form und Funktion kleinformatiger Porträts der römischen Kaiserzeit. Münster, Scriptorium.

Diebner, S. 1979. Aesernia - Venafrum, Untersuchungen zu den römischen Steindenkmälern zweier Landstädte Mittelitaliens. Archaeologica 8. Rom, Bretschneider.

Dobson, B. 1978. Die Primipilares. Beiheft Bonner Jahrbücher. Bonn, Habelt.

Keppie, L. J. F 1984. The Making of the Roman Army. London, Batsford. 
Künzl, E. 1996. Gladiusdekorationen der frühen Kaiserzeit: Dynastische Legitimation, Victoria und Aurea Aetas, Jahrbuch des Römisch-Germanischen Zentralmuseums 43, 2 , 383-474.

Künzl, E. 2009. Unter den goldenen Adlern. Mainz, Verlag des RGZM Mainz.

Liberatore, D. and Strazzulla, M. 2007. Fucino. Studi sulla cultura figurativa. Bari, Edipuglia.

Lipps, J. and Töpfer, K. M. 2007. Neues zum Grabbau des Marcus Paccius Marcellus im Kloster von San Guglielmo al Goleto. Römische Mitteilungen 113, 571-594.

Mlasowsky, A. 1996. Die Sukzessionpropaganda von Augustus bis Nero, Jahrbuch des Deutschen Archäologischen Instituts 111, 249-388.

Rose, C. B. 1997. Dynastic Commemoration and Imperial Portraiture in the Julio-Claudian Period. Cambridge, Cambridge University press.

Schäfer, T. 1989. Imperii Insignia, Sella curulis und fasces. Ergänzungsheft Römische Mitteilungen 29. Mainz, Zabern.

Smith, R. R. R. 2013. The Marble Reliefs from the Julio-Claudian Sebasteion. Mainz: Zabern.

Stoll, O. 1992. Die Skulpturenausstattung römischer Militäranlagen an Rhein und Donau. Pharos 1. St. Katharinan, Scriptae Mercaturae.

Strazzulla, M. J. 2001. Trasacco. Il monumento funerario dei Titecii, in A. Campanelli (ed.), Il Tesoro del Lago, 172-178. Pesacara, Carsa.

Töpfer, K. M. 2011. Signa Militaria - Die römischen Feldzeichen in der Republik und im Prinzipiat. Mainz, Verlag des RGZM Mainz.

Töpfer, K. M. 2009. Zur Funktion der Bildnismedaillons an römischen Feldzeichen, in A. W. Busch (ed.), Waffen in Aktion. Papers of the ROMEC XVI at Xanten 2007, 253-260. Mainz, Zabern.

Wood, S. E. 1999. Imperial Women. A study in public images 40 B.C. - A.D. 68. Leiden et al., Brill.

\section{Picture credits:}

Fig. 1. Courtesy of Landesmuseum Bonn.

Fig. 2. After E. Zwierlein-Diehl, Die antiken Gemmen des Kunsthistorischen Museums in Wien II (München 1979) pl. 71.

Fig. 3. Photo by author.

Fig. 4. After Alexandridis 2004, pl. 27, 2.

Fig. 5. Coinarchives.com. 